Article

\title{
Performance Evaluation and Life Cycle Cost Analysis Model of a Gondola-Type Exterior Wall Painting Robot
}

\author{
Dong-Jun Yeom ${ }^{1}$, Eun-Ji Na ${ }^{1}$, Mi-Young Lee ${ }^{1}$, Yoo-Jun Kim ${ }^{1}$, Young Suk Kim ${ }^{1, *}$ \\ and Chung-Suk Cho ${ }^{2}$ \\ 1 Department of Architectural Engineering, Inha University, Incheon 22212, Korea; dj09051@inha.edu (D.-J.Y.); \\ 22131041@inha.edu (E.-J.N.); 22141007@inha.edu (M.-Y.L.); 22162010@inha.edu (Y.-J.K.) \\ 2 Department of Civil, Infrastructure and Environmental Engineering, Khalifa University, P.O. Box 127788, \\ Abu Dhabi L2017E, UAE; chung.cho@kustar.ac.ae \\ * Correspondence: youngsuk@inha.ac.kr; Tel.: +82-32-860-7593
}

Received: 12 September 2017; Accepted: 6 October 2017; Published: 8 October 2017

\begin{abstract}
The amount and market size of apartment complex exterior wall painting work continues to increase each year in South Korea. Nevertheless, there are difficulties with the supply and demand of human resources due to the high risks associated with conventional painting work. To resolve these issues, research and development has recently been conducted on a Gondola-type Exterior Wall Painting robot (GEWPro). The aims of this study were to develop a performance evaluation and life cycle cost (LCC) analysis model for a GEWPro and deduce its performance and economic efficiency through a case study. According to the results, the performance of the automated method was $16.8 \%$ higher than that of the conventional method, and the economic efficiency was also superior (benefit/cost ratio 6.39). These results show that the proposed performance evaluation and LCC analysis model can predict the productivity and economic efficiency of automated methods.
\end{abstract}

Keywords: exterior wall painting; automation robot; life cycle cost; performance evaluation

\section{Introduction}

The number of newly constructed apartment complexes in South Korea continues to increase each year. In particular, apartment complexes containing more than 304,432 dwellings were constructed in 2016 [1]. Because the exterior finishes of these apartment complexes normally require painting, the increase in the supply of newly built apartment complexes will result in an increase in the demand for exterior wall painting. Moreover, in the case of existing apartment complexes to which exterior wall painting has been applied, full-scale repainting on the entire outer wall of an apartment should be performed every five years using a fresh coat of paint according to the long-term repair plan of the Korea Housing Act [2] to enhance the long-term durability and sustainability of the buildings. An analysis of the repainting frequency for 50 apartment complexes in metropolitan areas of South Korea showed that exterior wall repainting was performed every 5.34 years on average. Therefore, it is expected that the market for exterior wall painting of apartment complexes will grow even more in the future considering the enormous number of dwellings in apartment complexes in South Korea.

Exterior wall painting for apartment complexes is performed by laborers working from a suspended scaffold. Therefore, there is a high risk of accidents, such as falls or collisions with the outer wall. Moreover, there is a high risk of safety accidents, such as falling objects hitting pedestrians passing by below. In particular, the intensity of an accident would be very high when it does occur because exterior wall painting work is performed after the safety structures (safety net, flared shield in, etc.) have been removed from the exterior walls. Thus, the inherent problems, such 
as various risks and the number of insufficient skilled laborers involved in the exterior wall painting work of apartment complexes in South Korea, are expected to worsen in the future.

Recently, a unique Gondola-type Exterior Wall Painting robot (GEWPro) was developed to resolve the above problems related to the conventional exterior wall painting work of apartment complexes in South Korea [3]. To determine if this construction automation technology is attractive and acceptable in the field, it is important to verify quantitatively the benefits gained using the automated method by a comparison with the conventional method. Over the last three decades, a number of automated or semi-automated construction machines or systems have been developed and demonstrated in the construction industry [4-8]. On the other hand, few studies have verified the superiority of such automated methods based on a comparison and analysis of their overall performance in terms of productivity, cost, safety, and quality [9]. As a result, their practical use in the field has been underestimated.

In this study, the conventional process of the exterior wall painting of apartment complexes in South Korea and its problems were identified, and the automated method using the developed GEWPro was assessed. A model for performance evaluation and Life Cycle Cost (LCC) analysis [10-12] of GEWPro was developed in an effort to enhance the sustainability for the practical use of robots on construction sites.

Based on the model and data collected from several field trials, the overall performance of GEWPro was analyzed and its LCC was then compared with that of the conventional method to verify the benefits obtained from automation. Multiple laboratory and field tests were conducted to acquire essential data for the performance evaluation and LCC analysis. Conclusions and recommendations are made regarding the value of implementing and commercializing GEWPro. Finally, the performance evaluation and LCC analysis methodology and the model presented in this study can be adapted to analyze the performance of any other construction automation machine or robot.

\section{Background Studies}

\subsection{The Conventional Exterior Wall Painting Work Process and the Problems}

According to an analysis based on a field examination regarding exterior wall painting work currently performed in South Korea, the process of the exterior wall painting work can be categorized into the following: (1) preparation work; (2) installation work; (3) painting work; (4) disassembly work; (5) horizontal moving work; and (6) demobilization work. Figure 1 illustrates the detailed work process.

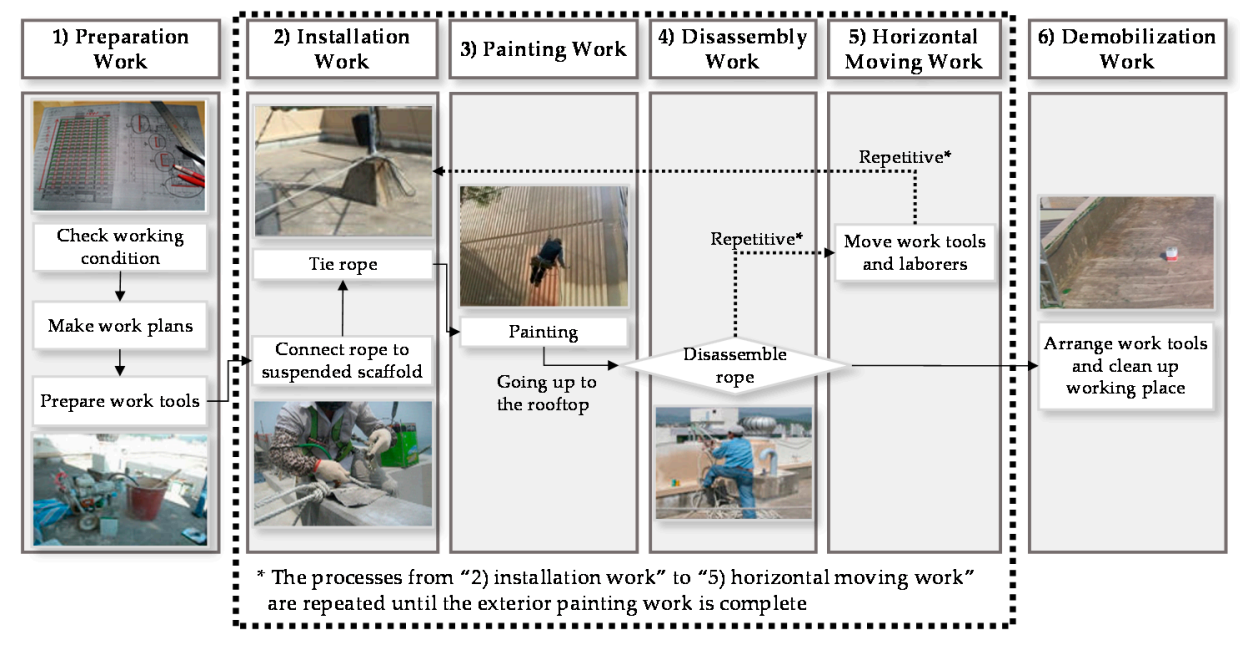

Figure 1. Conventional exterior wall painting work process. 
To understand the exterior wall painting work currently performed in South Korea and investigate the problems of the current method, a questionnaire including questions related to the following three major aspects (Sections 2.1.1-2.1.3) was distributed to 69 on-site field managers who work for seven construction companies (including both general and specialty contractors) in South Korea.

\subsubsection{Aspect of the Supply and Demand of Human Resources}

Conventional exterior wall painting work is strongly dependent on laborers, as shown by the ratio of the laborer cost to the total construction cost of $80 \%$ [13]. Therefore, the supply and demand of exterior wall painting laborers with good quality and construction speeds are very important factors for completing exterior wall painting work successfully and economically. On the other hand, there has always been a difficulty in the supply and demand of skilled laborers, because of the inherent high risks involved in the exterior wall painting work of high-rise apartment complexes. In the survey, all respondents also indicated that such laborer issues would continue to become much more serious in the near future considering that it generally takes approximately eight to nine years for an entry-level laborer to become a skilled laborer, and there is an undersupply.

\subsubsection{Aspect of Productivity and Quality}

According to the survey result regarding the productivity and quality aspects of the conventional exterior wall painting work, $57.8 \%$ of respondents perceived the following to be the most urgent problems to be solved in the aspects of productivity and quality: (1) a decrease in productivity due to the work done by insufficiently skilled laborers and unskilled laborers; and (2) inconsistent thickness of the painted surface due to manual work and deviations in the workmanship of the labor force, respectively. Most of the survey respondents also answered that such problems are expected to worsen in the future due to aging of the labor manpower and the phenomena of avoiding construction fields among the younger work force of South Korea.

\subsubsection{Aspect of Safety}

Conventional exterior wall painting is a high-risk type of work, in which the work is performed by a laborer while suspended in a hanging scaffold. According to the survey regarding the risk and safety aspects of the conventional exterior wall painting work, $66 \%$ of respondents answered that the risk of exterior wall painting work is still very high, and alternatives, such as automation (applying robots), need to be considered in an effort to prevent or minimize deadly accidents that can occur in the exterior wall painting work conducted by labor work force.

\subsection{Development Status of Gondola-Type Exterior Wall Painting Robot}

To resolve aforementioned problems, a GEWPro has recently been developed in South Korea for the automation of the exterior wall painting work in high-rise buildings [3]. In this study, the characteristics of the developed GEWPro based on its composition and specifications were analyzed to develop a performance evaluation and LCC analysis model [10-12]. The GEWPro is equipped with the capability for exterior wall painting of apartment complexes as its major function and is supplemented with a function for cleaning the outer walls as well. To perform painting and cleaning work, the GEWPro is composed of four parts-"main body of the robot", "hanger", "paint and cleaning water supply device", and a "controller". Figure 2 shows the composition of the main body of the developed GEWPro, and lists its detailed specifications. 


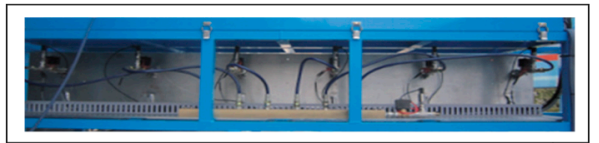

(a) Painting tool

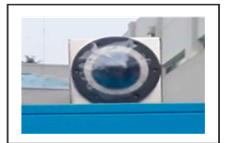

(h) Camera

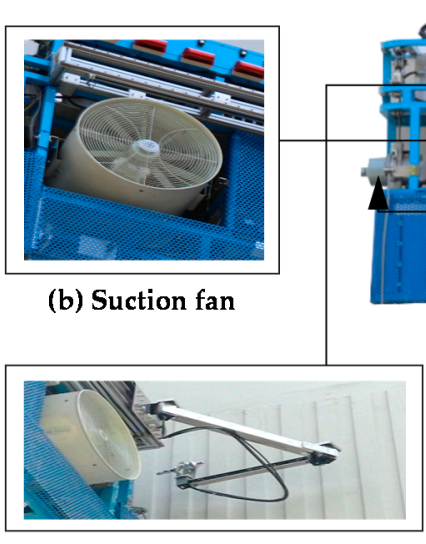

(c) Robot's arm

\begin{tabular}{|c|c|c|c|}
\hline \multicolumn{2}{|c|}{ Major Composition } & \multicolumn{2}{|c|}{ Specifications } \\
\hline \multirow{2}{*}{$\begin{array}{l}\text { Main body } \\
\text { of the robot }\end{array}$} & Weight & \multicolumn{2}{|l|}{ Approx. $680 \mathrm{~kg}$} \\
\hline & Size & \multicolumn{2}{|l|}{$2.6 \mathrm{~m} \times 1.9 \mathrm{~m}$} \\
\hline \multirow[b]{2}{*}{ Painting tool } & $\begin{array}{c}\text { Spraying } \\
\text { method }\end{array}$ & \multicolumn{2}{|c|}{ Multi-nozzle spray coating method } \\
\hline & Nozzle & \multicolumn{2}{|c|}{$\begin{array}{l}\text { No. } 615 * 6 \text { nozzles } \\
\text { (main body of the robot) } \\
\text { No. } 615 * 2 \text { nozzles (robot's arm) }\end{array}$} \\
\hline \multirow{2}{*}{ Suction fan } & Size & \multicolumn{2}{|l|}{$\emptyset 600 * 2$ fans } \\
\hline & Output & \multicolumn{2}{|l|}{$1,700 \mathrm{rpm}$} \\
\hline \multirow{2}{*}{$\begin{array}{l}\text { Robot's } \\
\text { arm }\end{array}$} & \multirow{2}{*}{$\begin{array}{l}\text { Working } \\
\text { range }\end{array}$} & Forward stroke & $250 \mathrm{~mm}$ \\
\hline & & Rotation angle & $0^{\circ} \sim 300^{\circ}$ \\
\hline \multirow{2}{*}{$\begin{array}{c}\text { Task } \\
\text { management } \\
\text { system }\end{array}$} & \multirow{2}{*}{$\begin{array}{l}\text { Shooting } \\
\text { range }\end{array}$} & $\begin{array}{l}\text { Horizontal } \\
\text { direction }\end{array}$ & $54.44^{\circ} \sim 4.64^{\circ}$ \\
\hline & & Vertical directior & $42.32^{\circ} \sim 3.58^{\circ}$ \\
\hline
\end{tabular}

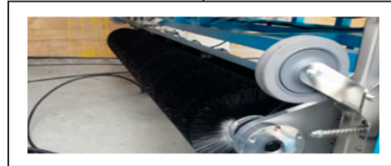

(d) Cleaning tool

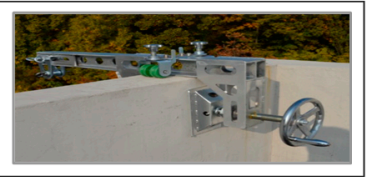

(g) Hanger

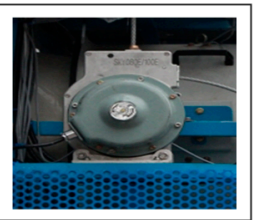

(f) Winder

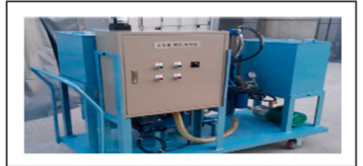

(e) Device for supply printing and cleaning work

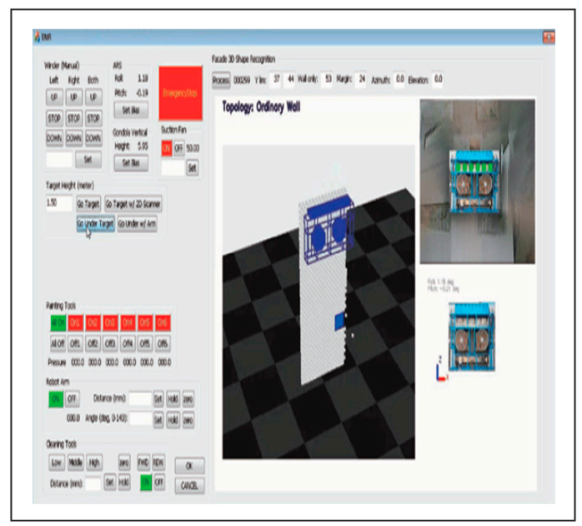

(i) Task management system

Figure 2. Major composition of GEWPro.

\subsubsection{Main Body of the GEWPro}

The main body of GEWPro consists of a camera, painting tool, robot's arms, winder, suction pan, and a cleaning tool. The painting tool is the main device for performing exterior wall painting work and can carry out the exterior wall painting work through six nozzles that are equipped with an anti-scattering cover. The robot arms of GEWPro were installed to enable the simultaneous painting of the protruding areas and blind spots of the external walls without additional work and could perform the painting work through two nozzles. The suction fan was designed to improve wind resistance performance of GEWPro and maintain a consistent distance between the exterior wall and main body of GEWPro during the exterior wall painting. Using the two suction fans installed in the main body of GEWPro, it is possible to perform stable painting work and overcome protruding obstacles while moving up or down. Winder and endless wires are designed to minimize the risk of falling accidents of GEWPro. In addition, a camera attached to the main body of GEWPro allows real-time monitoring of the condition and painting quality of the exterior wall painting work. A cleaning tool has been designed to clean the outer walls, if necessary, by brushing and washing with water. 


\subsubsection{Hanger}

The hanger has been developed to enable the lifting of GEWPro from a rooftop in the form shown in Figure 2g, and it can be easily installed, disassembled, and moved horizontally in the rooftop (parapet) without additional equipment. The system was designed to be small and light to increase the ease of work, and it can be applied to apartment complex rooftops (parapet) of various thicknesses with easy installation and disassembling.

\subsubsection{Paint and Water Supply Device}

The paint and water supply device was designed to be located on the ground to reduce the weight of GEWPro and the convenience of the work, and it was developed as an integrated device for the airless pump and solution tank (Figure 2e).

\subsubsection{Task Management System}

The GEWPro was designed to be able to scan the outer wall in three dimensions and automatically detect obstacles and openings on the exterior walls while moving up from the ground. Based on this scanning information, the system performs painting work by automatically making judgments about the areas to be painted while moving down. As shown in Figure 2i, a task management system (controller) was developed to allow an operator to monitor and control the current status of GEWPro and the overall condition of the painting work being conducted in real time using a camera attached to the upper part of the robot (Figure 2h).

\subsubsection{Work Process of the GEWPro}

According to an analysis based on a field examination regarding the exterior wall painting work that is being performed by GEWPro, the process of the exterior wall painting work by GEWPro can be categorized into the following: (1) preparation work; (2) installation work; (3) painting work; (4) disassembly work; (5) horizontal moving work; and (6) demobilization work. Figure 3 presents the detailed work process.

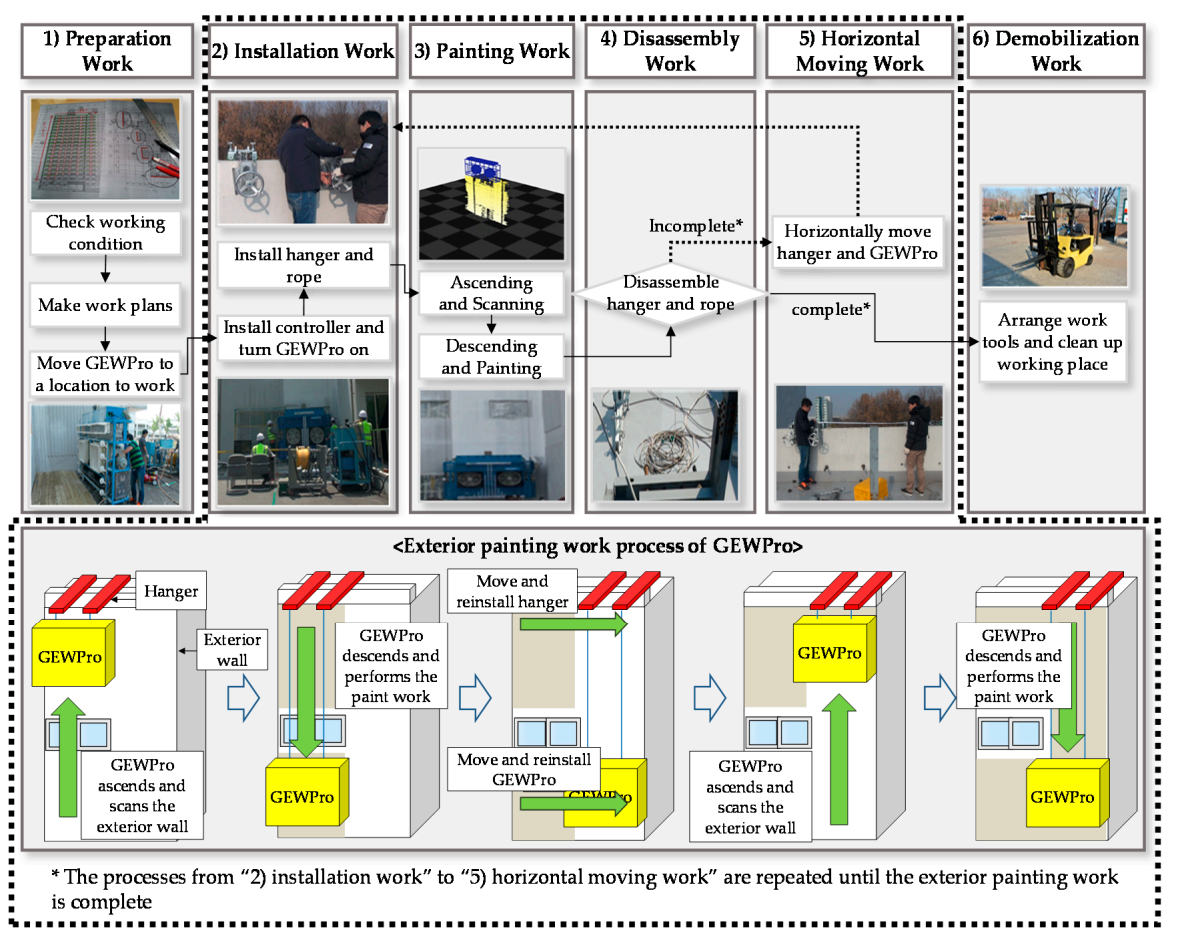

Figure 3. Major composition of GEWPro. 


\section{Development of Performance Evaluation and LCC Analysis Model of GEWPro}

If the economic validity of automated construction robots were not secured, it would be difficult to introduce them to an actual construction field even if their safety and productivity are far superior to the conventional method. Therefore, proving the advantage of an automated method over the conventional method through economic validity analysis is crucial to the research, development, and commercialization of automated construction robots [14]. Thus, this study aims to develop a performance evaluation and LCC analysis model (Figure 4) that reflects the characteristics of building exterior painting work as well as the specifications and performance of GEWPro and verifies the validity of the proposed model and commercialization possibility of GEWPro through a case study.

\subsection{Performance Evaluation Model of GEWPro}

The performance evaluation model (Figure 4-Step 2) developed in this study appraised the performance of GEWPro by analyzing the resources required for exterior wall painting work per day, work time, and work productivity. As shown in Figures 1 and 3, work processes starting from "preparation work" through "horizontal moving work" are basically identical in the conventional method and automated method using GEWPro. The difference in productivity between the two methods stems from the difference in allocated resource amount (equipment, labor, etc.) and the required hours of work. In this study, the performance evaluation of GEWPro was carried out by comparing the productivity between conventional and automated methods resulting from work processes starting from "preparation work" through to "horizontal moving work" excluding the "demobilization work", which typically occurs after the daily working hours (8 hours/day).

\subsection{LCC Analysis Model of GEWPro}

The LCC analysis of GEWPro can be carried out by analyzing and calculating the additional cost incurred in exterior wall painting work using GEWPro (compared to that of the conventional method) and the benefits derived from the introduction of this automated method [15]. In this study, reasonable assumptions were made to conduct an economic analysis of GEWPro and the LCC analysis model that reflects the initial cost, maintenance cost, interest rate, number of workable days per year, possible total exterior painting area per year, and net profit per year resulting from the automated method was suggested. In addition, the economic feasibility of GEWPro was verified through a case study. For the means of economic analysis of GEWPro, (1) net present worth; (2) benefit/cost ratio; and (3) break-even point analyses were used; and (4) cost saving effect analysis of the automated method being introduced was conducted.

\subsection{Sensitivity Analysis Model}

In this study, the major factors that influence the performance evaluation and LCC analysis of GEWPro were identified and sensitivity analysis was performed on those factors to improve the reliability of the performance evaluation and LCC analysis result. Figure 4-Step 4 presents a model for sensitivity analysis. 
Step 1: Selection of a Building to Analyze

\begin{tabular}{|l|l|}
\hline Step 1.1 & Select a building to be painted \\
\hline Step 1.2 & Analyze Total Painting Area of the building (TPA) \\
\hline
\end{tabular}

\section{Step 2: Performance Evaluation}

\begin{tabular}{|l|l|}
\hline Step 2.1 & $\begin{array}{l}\text { Analyze resources required for exterior wall painting } \\
\text { work per day in both conventional and automated methods }\end{array}$ \\
\hline Resources required for the conventional painting work per day $\left(\mathrm{R}_{\mathrm{C}}\right)=$ \\
Equipment $\left(\mathrm{r}_{\mathrm{EC}}\right)+$ Laborer $\left(\mathrm{r}_{\mathrm{LC}}\right)+$ Consumables $\left(\mathrm{r}_{\mathrm{CC}}\right)+$ Material $\left(\mathrm{r}_{\mathrm{MC}}\right)$ \\
\hline Resources required for the automated painting work per day $\left(\mathrm{R}_{\mathrm{G}}\right)=$ \\
\hline Equipment $\left(\mathrm{r}_{\mathrm{EG}}\right)+$ Laborer $\left(\mathrm{r}_{\mathrm{LG}}\right)+$ Consumables $\left(\mathrm{r}_{\mathrm{CG}}\right)+$ Material $\left(\mathrm{r}_{\mathrm{MG}}\right)$
\end{tabular}

\begin{tabular}{|c|c|c|c|c|c|}
\hline \multicolumn{6}{|c|}{ Step 2.2 Analyze work time in both conventional and automated methods } \\
\hline \multicolumn{6}{|c|}{$\begin{array}{l}\text { Measure the actual time of each work process in the conventional method } \\
\text { Calculate the Total work time of the conventional method }\left(\mathrm{T}_{\mathrm{C}}\right)\end{array}$} \\
\hline \multicolumn{6}{|c|}{$\begin{array}{l}\text { Measure the actual time of each work process in the automated method by GEW Pro } \\
\text { Calculate Total work time of the automated method }\left(\mathrm{T}_{\mathrm{G}}\right)=\end{array}$} \\
\hline $\begin{array}{c}\text { Preparation } \\
\text { W ork }\end{array}$ & $+\begin{array}{c}\text { Installation } \\
\text { Work }\end{array}$ & $+\begin{array}{c}\text { Painting } \\
\text { Work }\end{array}$ & $+\underset{\begin{array}{c}\text { Disassembly } \\
\text { Work }\end{array}}{ }$ & + & $\begin{array}{l}\text { Horizontal } \\
\text { Moving Work }\end{array}$ \\
\hline
\end{tabular}

\begin{tabular}{|l|}
\hline Step $2.3 \begin{array}{l}\text { Analyze work productivity in both conventional } \\
\text { and automated methods }\end{array}$ \\
\begin{tabular}{|l|} 
Work Productivity of the conventional method per hour $\left(W P h_{C}\right)$ \\
$=T P A / T c$
\end{tabular} \\
$\begin{array}{c}\text { Labor Produdivity of a Painter in the conventional method (LPP } \\
=W P h_{C}\end{array}$ 8 8hr of daily work hours / (number of painters on a day)
\end{tabular}

Work Productivity of the automated method per hour $\left(W P h_{G}\right)$
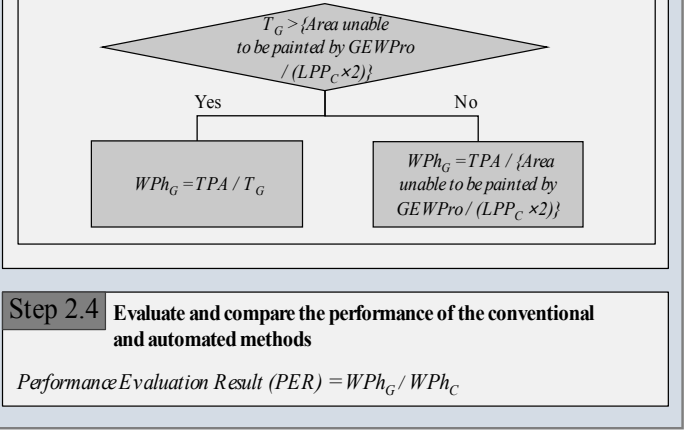

\begin{tabular}{|l|l|}
\hline \multicolumn{2}{|c|}{ Step 4: Sensitivity Analysis } \\
\hline Step 4.1 & Establish the variables for sensitivity analysis \\
\hline Step 4.2 & Sensitivity analysis \\
\hline
\end{tabular}

\section{Step 3: LCC Analysis}

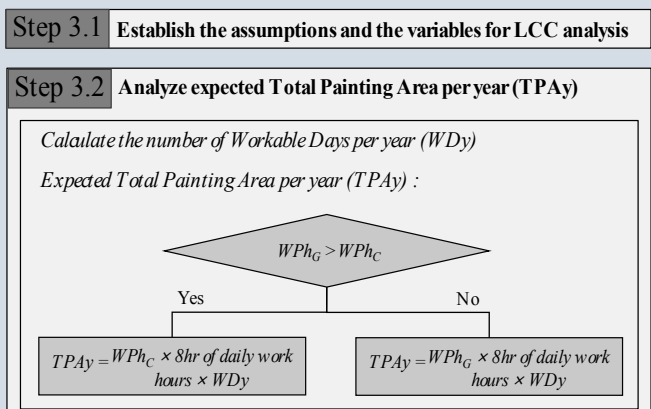

Step 3.3 Analyze Annual Benefit by the automated method (AB)

Expenses of the conventional method per $\mathrm{m}^{2}\left(\mathrm{Em}^{2} \mathrm{C}\right.$

$=\left(\mathrm{r}_{\mathrm{LC}}+\mathrm{r}_{\mathrm{CC}}+\mathrm{r}_{\mathrm{MC}}\right) \times$ expenses of the resources $/\left(W P h_{C} \times 8 h r\right)$

Expenses of the automated method per $m^{2}\left(E m_{G}^{2}\right)$

$=\left(\mathrm{r}_{\mathrm{LG}}+\mathrm{r}_{\mathrm{CG}}+\mathrm{r}_{\mathrm{MG}}\right) \times$ expenses of the resources $/\left(W P h_{G} \times 8 h r\right)$

Annual Benefit by the automated method (AB)

$=\left(E m_{C}^{2}-E m_{G}^{2}\right) \times T P A y$ (8hr: daily work hours)

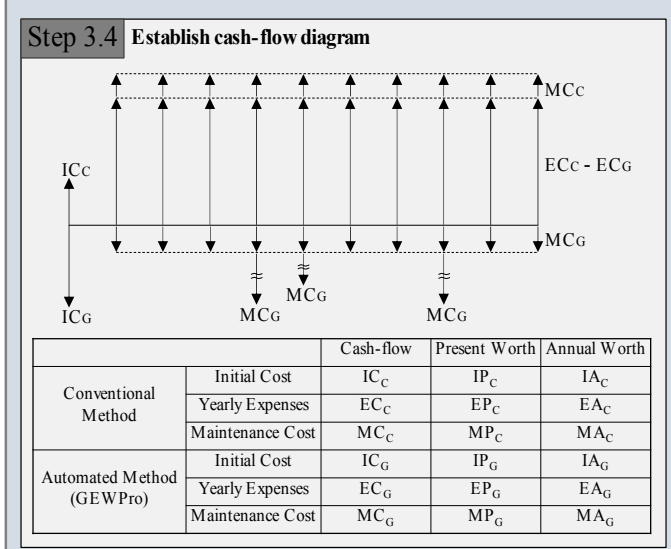

\begin{tabular}{|l|l}
\hline Step 3.5 & Analyze LCC by the automated method using GEWPro
\end{tabular}

Net Present Worth

$=$ Present worth of benefit - Present worth of cast $=\left(E P_{C^{-}} E P_{G}\right)-\left\{\left(I P_{G^{-}} I P_{C}\right)+\left(M P_{G^{-}}-M P_{C}\right)\right\}$

Benefit/Cost Ratio

$=$ Present worth of benefit $/$ Present worth of cost

$=\left(E P_{C}-E P_{G}\right) /\left\{\left(I P_{G}-I P_{C}\right)+\left(M P_{G}-M P_{\partial}\right\}\right.$

Cost Saving Effect using Equivalent Annual Worth Method

$=$ (Annual cost of Conventional Method - Annual cost of Automated Method) / Annual cost of Conventional Method

$=\left\{\left(I A_{C}+E A_{C}+M A_{C}\right)-\left(I A_{G}+E A_{G}+M A_{G}\right)\right\} /\left(I A_{C}+E A_{C}+M A_{C}\right)$

Break-even Point

$\Rightarrow$ Finding the year $(n)$ when Present worth of benefit $=$ Present worth of Cost

$\Rightarrow \frac{(1+i)^{n}-1}{i(1+i)^{n}}=\left\{\left(I P_{G}-I P_{C}\right)+\left(M P_{G}-M P_{C}\right)\right\} /\left(E A_{C}+E A_{G}\right)$

Figure 4. Performance evaluation and LCC analysis model of GEWPro.

\section{Performance Evaluation and LCC Analysis of GEWPro}

\subsection{Buildings for the Case Study}

For a performance evaluation and LCC analysis of GEWPro, apartment complexes comprised of residences, $99.0 \sim 115.5 \mathrm{~m}^{2}$ in size, which form the highest proportion $(24 \%)$ among all apartments being built in South Korea [1], were considered for the case study. Two apartment complex construction sites, 
Chungbuk Jincheon (Site A) and Gangwon Wonju (Site B), where exterior wall painting work was in progress at the time of this study, were selected (Table 1). From the floor plans for both sites, the total painting area of Sites A and B was $8275.0 \mathrm{~m}^{2}$ and $8013.3 \mathrm{~m}^{2}$, respectively, while the total painting area excluded from the study due to the difficulty of GEWPro access (bold lines of Table 1) was $2446.8 \mathrm{~m}^{2}$ and $1841.0 \mathrm{~m}^{2}$ for Sites A and B, respectively (Table 1).

Table 1. Floor plan and outline of the buildings for the case study.

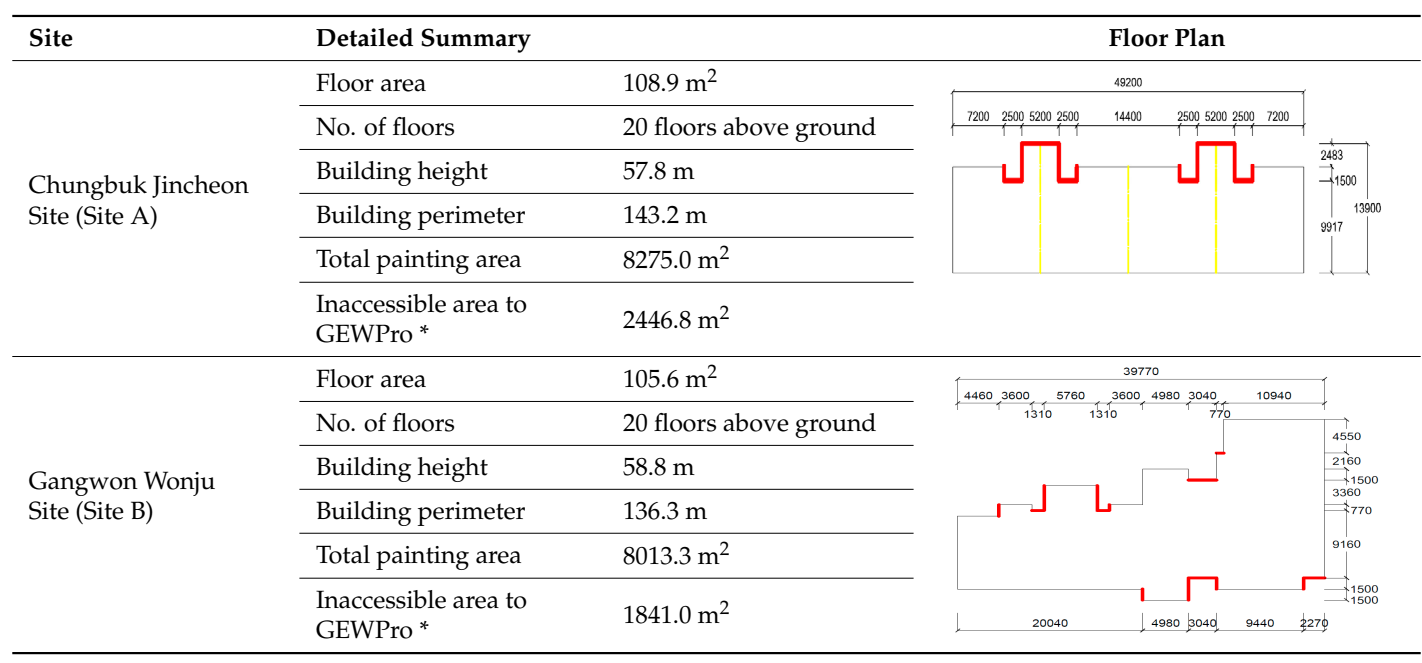

* Inaccessible area to GEWPro can be defined as follows: Places where hangers cannot be installed on the parapet of a rooftop because the parapet is not continuously connected or where the width of the area to be painted is more narrow than $2.6 \mathrm{~m}$, the width of GEWPro.

\subsection{Performance Evaluation of GEWPro}

\subsubsection{Daily Resource Analysis of Conventional and Automated Methods Using GEWPro}

As summarized in Table 2, daily resources $\left(R_{C}, R_{G}\right)$ consisting of the equipment, laborer, consumables, material, etc. required for conventional exterior painting work and automated method using GEWPro were identified based on an interview conducted with exterior painting work experts as well as field test results using GEWPro.

Table 2. Daily resource analysis of the conventional and automated methods using GEWPro.

\begin{tabular}{|c|c|c|c|c|}
\hline \multirow{2}{*}{ Item } & & \multicolumn{2}{|c|}{ Conventional Method } & \multirow{2}{*}{ GEWPro } \\
\hline & & Site A & Site B & \\
\hline \multirow{2}{*}{ Equipment $\left(\mathrm{r}_{\mathrm{E}}\right)$} & GEWPro & - & - & 1 ea. \\
\hline & Airless pump & 4 ea. & 3 ea. & 2 ea. \\
\hline \multirow{6}{*}{ Laborer $\left(\mathrm{r}_{\mathrm{L}}\right)$} & Foreman & 1 & - & 1 \\
\hline & Painter (Spray coating) & 4 & 3 & 2 \\
\hline & Painter (Roller, Brush) & - & 2 & 1 \\
\hline & Laborer (Helper, Safety) & 1 & 1 & 1 \\
\hline & Operator & - & - & 1 \\
\hline & Total & 6 & 6 & 6 \\
\hline \multirow{3}{*}{ Consumables $\left(\mathrm{r}_{\mathrm{C}}\right)$} & Spray gun & 4 & 3 & 2 \\
\hline & Hose & 4 & 3 & 2 \\
\hline & Nozzle tip & 4 & 3 & 2 \\
\hline Material $\left(\mathrm{r}_{\mathrm{M}}\right)$ & Paint & $0.24 \ell / \mathrm{m}^{2}$ & $0.24 \ell / \mathrm{m}^{2}$ & $0.24 \ell / \mathrm{m}^{2}$ \\
\hline
\end{tabular}




\subsubsection{Total Work Time Analysis of Conventional and Automated Methods Using GEWPro}

The total work time required for conventional exterior painting work and the automated method using GEWPro was analyzed using the work sampling technique according to Step 2.2 of Figure 4 . The results show that using the conventional method, the total time required for exterior wall painting work $\left(\mathrm{T}_{\mathrm{C}}\right)$ for a single apartment building on both sites (Site A and B) was 3 days (24 h), whereas the automated method using GEWPro $\left(T_{G}\right)$ took $20.9 \mathrm{~h}$ for Site A and $20.2 \mathrm{~h}$ for Site B for a single apartment building (Table 3). The total work time using GEWPro excludes painting work for areas not accessible by GEWPro (bold lines of Table 1).

Table 3. Analysis of the total work time required using GEWPro on a single apartment building.

\begin{tabular}{cccc}
\hline \multirow{2}{*}{ Work Process } & \multicolumn{2}{c}{ Required Work Time } & Comment \\
\cline { 2 - 4 } & Site A & Site B & Performed once initially \\
\hline Preparation Work & \multicolumn{2}{c}{$30.0 \mathrm{~min}}$. \\
\hline Installation Work & $42.8 \mathrm{~min}$. & Performed once initially \\
\hline Painting Work & $820.4 \mathrm{~min}$. & $796.6 \mathrm{~min}$. & Ascend/descend speed $6.2 \mathrm{~m} / \mathrm{min}$. \\
\hline $\begin{array}{c}\text { Disassembly Work and } \\
\text { Horizontal Moving Work }\end{array}$ & $361.2 \mathrm{~min}$. & $344.4 \mathrm{~min}$. & $\begin{array}{c}\text { Dismantling and horizontal movement } \\
\text { time } 8.4 \text { min / event }\end{array}$ \\
\hline Total & $\begin{array}{c}1254.4 \mathrm{~min} \\
(20.9 \mathrm{~h})\end{array}$ & $\begin{array}{c}1213.8 \mathrm{~min} \\
(20.2 \mathrm{~h})\end{array}$ & \\
\hline
\end{tabular}

\subsubsection{Work Productivity Analysis of Conventional and Automated Methods Using GEWPro}

As summarized in Table 4, the hourly work productivity of the conventional method and automated method using GEWPro $\left(\mathrm{WPh}_{\mathrm{C}}, \mathrm{WPh}_{\mathrm{G}}\right.$, respectively) and single painter's hourly productivity $\left(\mathrm{LPP}_{\mathrm{C}}\right)$ were analyzed according to Step 2.3 of Figure 4 . Regarding the exterior painting area, where GEWPro was not accessible (bold lines of Table 1), two additional painters were deployed to carry out the work. Because the conventional exterior painting work and automated method using GEWPro can be done concurrently without any mutual interference, the total required work time used to calculate GEWPro work productivity was determined by taking the larger value between $\mathrm{T}_{\mathrm{G}}$ and $\mathrm{LPP}_{\mathrm{C}} \times 2$, which was the time required for two additional painters deployed to work on areas not accessible by GEWPro. Because the time taken for two additional painters to complete the painting work for areas not accessible by GEWPro was less than $\mathrm{T}_{\mathrm{G}}$ on both case study buildings, the total work time of GEWPro $\left(\mathrm{T}_{\mathrm{G}}\right)$ was used in GEWPro work productivity analysis (Figure 4-Step 2.3).

Table 4. Work productivity analysis result.

\begin{tabular}{|c|c|c|c|c|}
\hline \multirow{2}{*}{ Each Building } & \multicolumn{2}{|c|}{ Conventional Method } & \multicolumn{2}{|c|}{ GEWPro } \\
\hline & Site A & Site B & Site A & Site B \\
\hline Painting area & $8275.3 \mathrm{~m}^{2}$ & $8013.3 \mathrm{~m}^{2}$ & $8275.0 \mathrm{~m}^{2}$ & $8013.3 \mathrm{~m}^{2}$ \\
\hline Total time required & $24 \mathrm{~h}$ & $24 \mathrm{~h}$ & $20.9 \mathrm{~h}$ & $20.2 \mathrm{~h}$ \\
\hline Hourly work productivity & $344.8 \mathrm{~m}^{2} / \mathrm{h}$ & $333.9 \mathrm{~m}^{2} / \mathrm{h}$ & $396.2 \mathrm{~m}^{2} / \mathrm{h}$ & $396.5 \mathrm{~m}^{2} / \mathrm{h}$ \\
\hline Average hourly work productivity for both sites & \multicolumn{2}{|c|}{$339.4 \mathrm{~m}^{2} / \mathrm{h}$} & \multicolumn{2}{|c|}{$396.4 \mathrm{~m}^{2} / \mathrm{h}$} \\
\hline Work productivity of single painter & $86.2 \mathrm{~m}^{2} / \mathrm{M} \cdot \mathrm{h}$ & $66.8 \mathrm{~m}^{2} / \mathrm{M} \cdot \mathrm{h}$ & $86.2 \mathrm{~m}^{2} / \mathrm{M} \cdot \mathrm{h}$ & $66.8 \mathrm{~m}^{2} / \mathrm{M} \cdot \mathrm{h}$ \\
\hline Work time required for areas not accessible by GEWPro & - & - & $14.2 \mathrm{~h}$ & $13.8 \mathrm{~h}$ \\
\hline
\end{tabular}

\subsubsection{Performance Evaluation of GEWPro}

According to Step 2.4 in Figure 4, a performance evaluation of GEWPro was conducted using Equation (1). In calculating and analyzing the difference in productivity between the conventional and automated methods, the average hourly work productivities $\left(\mathrm{WPh}_{\mathrm{C}}, \mathrm{WPh}_{\mathrm{G}}\right)$ obtained from Sites $A$ and $B$ for each method was used for a performance evaluation. Performance evaluation analysis 
showed that the productivity of an automated method using GEWPro $\left(\mathrm{WPh}_{\mathrm{G}}\right)$ was $16.8 \%$ higher than that of the conventional method $\left(\mathrm{WPh}_{\mathrm{G}}\right)$.

$$
\begin{gathered}
\text { Performance Evaluation Result }(\text { PER }) \\
=\left(\text { Work Productivity of the automated method per hour }\left(W P h_{C}\right)\right) \\
\text { / Work Productivity of the conventional method per hour }\left(W P h_{G}\right) \\
=\left(396.4 \mathrm{~m}^{2} / \mathrm{h}\right) /\left(339.4 \mathrm{~m}^{2} / \mathrm{h}\right)=1.168
\end{gathered}
$$

\subsection{LCC Analysis of GEWPro}

4.3.1. Establishment of the Assumptions and the Variables for LCC Analysis

Prior to performing LCC analysis, assumptions and variables necessary for LCC analysis were established, as shown in Table 5 below.

Table 5. Assumptions and variables for LCC analysis.

\begin{tabular}{cccc}
\hline \multicolumn{2}{c}{ Assumptions and Variables } & Value & Value Setting Basis \\
\hline \multirow{2}{*}{$\begin{array}{c}\text { Interest Rate } \\
\text { Conventional } \\
\text { Method }\end{array}$} & Initial Cost & $2.90 \%$ & $\begin{array}{c}\text { Average inflation rate of South } \\
\text { Korea in recent 10 years }\end{array}$ \\
\cline { 2 - 4 } & Maintenance Cost & $\$ 14,494$ & Airless pump cost \\
\cline { 2 - 4 } & Expected Service Life & 10 year & Airless pump maintenance cost \\
\hline \multirow{2}{*}{ GEWPro } & Initial Cost & $\$ 60,568$ & Airless pump specification \\
& & $\begin{array}{c}\text { Annually } \\
(\$ 716)\end{array}$ & \\
& Maintenance Cost & $\begin{array}{c}\text { Every } 4 \text { years } \\
(\$ 16,099)\end{array}$ & $\begin{array}{c}\text { Replacement costs of detailed } \\
\text { parts per varying durability }\end{array}$ \\
& & $\begin{array}{c}\text { Every } 5 \text { years } \\
(\$ 6577)\end{array}$ & \\
& & 10 year & Life expectancy of GEWPro \\
\hline
\end{tabular}

\subsubsection{Analysis of Expected Total Painting Area per Year}

Set as a standard workload in performing the LCC analysis, the expected total painting area per year (TPAy) was calculated by multiplying the number of workable days per year (WDy: day/year) by the daily exterior wall painting work productivity $\left(\mathrm{WPh}_{\mathrm{C}} \times 8 \mathrm{~h}: \mathrm{m}^{2} /\right.$ day). By establishing the unworkable conditions (i.e., average daily temperature of $\leq 5^{\circ} \mathrm{C}$; highest daily temperature of $\geq 35^{\circ} \mathrm{C}$; daily precipitation of $\geq 10 \mathrm{~mm}$; daily maximum wind speed of $\geq 10 \mathrm{~m} / \mathrm{s}$; and national holidays) derived based on the Suspended Scaffold Safety Regulations of Korea Occupational Safety and Health Agency (KOSHA) [16] and the Painting Specifications of Korea Land and Housing Corporation [17] and by analyzing the recent ten years of weather data [18], the number of yearly workable days (WDy) was calculated to be 162 days. As shown in Step 3.2 of Figure 4, this yearly workable days (WDy) is multiplied by the smaller of the $\mathrm{WPh}_{\mathrm{C}}$ and $\mathrm{WPh}_{\mathrm{G}}$ to obtain the possible total painting area per year (TPAy). In this study, the TPAy required for LCC analysis was calculated to be $439,862.4 \mathrm{~m}^{2} /$ year according to Equation (2).

Expected Total Painting Area per year (TPAy)

$=$ Work Productivity of the automated per hour $\left(\mathrm{WPh}_{\mathrm{C}}\right) \times 8 \mathrm{~h} /$ day

$x$ the number of Workable Days per year (WDy)

$$
=\left(339.4 \mathrm{~m}^{2} / \mathrm{h}\right) \times 8 \mathrm{~h} / \text { day } \times(162 \text { day } / \text { year })=439,862.4 \mathrm{~m}^{2} / \text { year }
$$




\subsubsection{Annual Benefit Analysis of the Automated Method Using GEWPro}

According to Step 3.3 in Figure 4, the annual net profit of introducing the automated method using GEWPro was calculated by multiplying the expected total painting area per year (TPAy) by the difference between the expenses of the conventional method per square meter $\left(\mathrm{Em}^{2} \mathrm{C}\right)$ and the automated method per square meter $\left(\mathrm{Em}^{2}{ }_{\mathrm{G}}\right)$. The expenses per unit area $\left(\mathrm{m}^{2}\right)$ for conventional and automated methods were taken from the sum of all the necessary expenses of applied resources (laborer, consumables, material) excluding the equipment expense, which is applied directly to the cash-flow diagram. In measuring the expenses for resources, the unit prices actually utilized in the field were applied. As shown in Table 6, which summarizes the resources and expenses for conventional and automated methods, the expenses of the conventional method per unit area $\left(\mathrm{Em}^{2} \mathrm{C}\right)$ were $\$ 0.9351 / \mathrm{m}^{2}$, whereas the expenses for automated method per unit area $\left(\mathrm{Em}^{2} \mathrm{G}\right)$ were calculated to be $\$ 0.7998 / \mathrm{m}^{2}$. Therefore, the annual present worth benefit (AB) of applying GEWPro was calculated to be $\$ 59,520.1 /$ year according to Equation (3).

Annual Benefit by the automated method (AB)

$$
\begin{aligned}
&=\left(\text { Expenses of the conventional method per } \mathrm{m}^{2}\left(\mathrm{Em}^{2} \mathrm{C}\right)\right. \\
&- \text { Expenses of the automated method per } \mathrm{m}^{2}\left(\mathrm{Em}_{\mathrm{G}}{ }_{\mathrm{G}}\right) \\
& \times \text { Expected Total Painting Area per year }(\mathrm{TPAy}) \\
&=\left(\$ 0.9351 / \mathrm{m}^{2}-\$ 0.7998 / \mathrm{m}^{2}\right) \times 439,862.4 \mathrm{~m}^{2} / \text { year }=\$ 59,520.1 / \text { year }
\end{aligned}
$$

\begin{tabular}{|c|c|c|c|c|c|c|c|}
\hline \multicolumn{3}{|c|}{ Category } & \multicolumn{3}{|c|}{ Conventional Method } & \multicolumn{2}{|c|}{ GEWPro } \\
\hline \multirow{2}{*}{\multicolumn{2}{|c|}{ Resources }} & \multirow{2}{*}{ Unit Price } & \multicolumn{2}{|c|}{ Resources Applied } & \multirow{2}{*}{$\begin{array}{l}\text { Daily Work Expenses } \\
\text { (\$): Average of Two Sites }\end{array}$} & \multirow{2}{*}{$\begin{array}{l}\text { Resources } \\
\text { Applied }\end{array}$} & \multirow{2}{*}{$\begin{array}{r}\text { Daily Work } \\
\text { Expenses (\$) }\end{array}$} \\
\hline & & & Site A & Site B & & & \\
\hline \multirow{3}{*}{ Consumables } & Spray gun & \multirow{3}{*}{$\$ 13.9 /$ unit } & \multirow{3}{*}{4 items } & \multirow{3}{*}{3 items } & \multirow{3}{*}{$\$ 48.5$} & \multirow{3}{*}{2 items } & \multirow{3}{*}{$\$ 27.7$} \\
\hline & Hose & & & & & & \\
\hline & Tip & & & & & & \\
\hline \multirow{5}{*}{ Laborer } & Foreman & $\begin{array}{l}\$ 93.4 \text { per } \\
\text { person }\end{array}$ & 1 & - & \multirow{5}{*}{$\$ 1209.8$} & 1 & \multirow{5}{*}{$\$ 1009.3$} \\
\hline & $\begin{array}{c}\text { Painter } \\
\text { (Spray coating) }\end{array}$ & $\begin{array}{l}\$ 239.9 \text { per } \\
\text { person }\end{array}$ & 4 & 3 & & 2 & \\
\hline & $\begin{array}{c}\text { Painter } \\
\text { (Roller, Brush) }\end{array}$ & $\begin{array}{l}\$ 219.1 \text { per } \\
\text { person }\end{array}$ & - & 2 & & 1 & \\
\hline & Laborer & $\begin{array}{l}\$ 115.5 \text { per } \\
\text { person }\end{array}$ & 1 & 1 & & 1 & \\
\hline & Driver & $\begin{array}{l}\$ 101.5 \text { per } \\
\text { person }\end{array}$ & - & - & & 1 & \\
\hline Material & Paint & $\$ 2.6 / \ell$ & $481.3 \ell$ & $508 \ell$ & $\$ 1280.6$ & $578 \ell$ & $\$ 1496.6$ \\
\hline \multicolumn{3}{|c|}{ Daily work expenses } & \multicolumn{3}{|c|}{$\$ 2538.9 /$ day } & \multicolumn{2}{|c|}{$\$ 2533.6 /$ day } \\
\hline \multicolumn{3}{|c|}{ Daily work productivity } & \multicolumn{3}{|c|}{$2714.7 \mathrm{~m}^{2} /$ day } & \multicolumn{2}{|c|}{$3167.6 \mathrm{~m}^{2} /$ day } \\
\hline \multicolumn{3}{|c|}{ Expenses per unit area $\left(\mathrm{m}^{2}\right)$} & \multicolumn{3}{|c|}{$\$ 0.9351 / \mathrm{m}^{2}$} & \multicolumn{2}{|c|}{$\$ 0.7998 / \mathrm{m}^{2}$} \\
\hline
\end{tabular}

Table 6. Resources and expenses for the conventional and automated methods.

\subsubsection{Cash-Flow Diagram for LCC Analysis of GEWPro}

Using the set assumptions and variables established previously and reflecting the expenses calculated for conventional and automated methods, Figure 5 presents the cash-flow diagram of GEWPro for the durability life of 10 years. Table 7 also lists the net present worth (NPW) and equivalent annual worth (EAW) derived from the annual benefit by the automated method (AB), which was reflected in the cash-flow diagram and necessary expenses (i.e., initial cost, maintenance cost) of equipment resources $\left(\mathrm{r}_{\mathrm{EC}}, \mathrm{r}_{\mathrm{EG}}\right)$ for conventional and automated methods according to Step 3.4 of Figure 4 . 


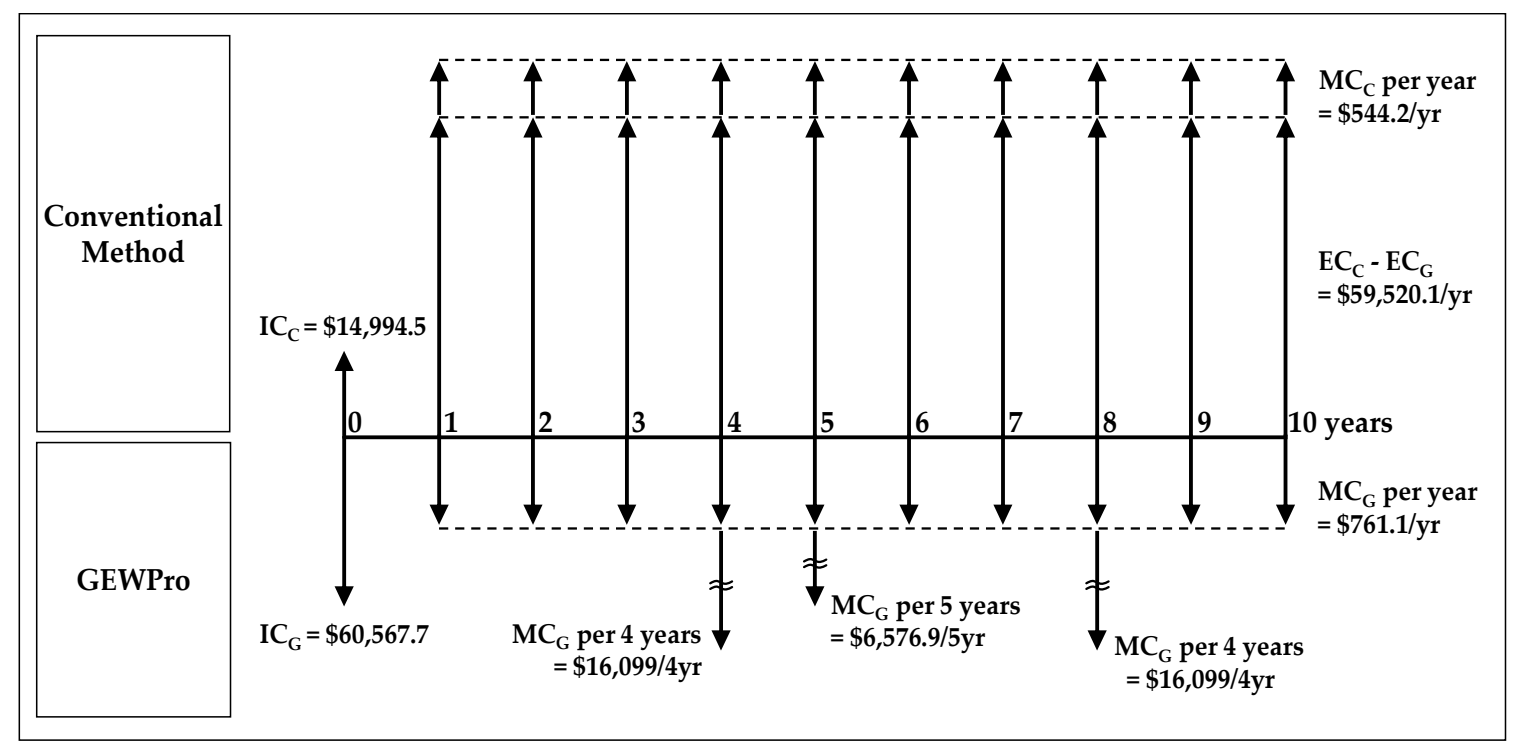

Figure 5. Cash-flow diagram for GEWPro's LCC analysis.

Table 7. Cash-flow analysis (present worth and annual worth).

\begin{tabular}{|c|c|c|c|c|c|}
\hline & & & $\begin{array}{l}\text { Cash-Flow } \\
\text { Diagram }\end{array}$ & Present Worth & Annual Worth \\
\hline \multirow{3}{*}{$\begin{array}{l}\text { Conventional } \\
\text { method }\end{array}$} & \multicolumn{2}{|c|}{ Initial cost } & $\$ 14,994.5$ & $\$ 14,994.5$ & $\$ 1748.9 /$ year \\
\hline & \multicolumn{2}{|c|}{ Yearly Expenses } & $\$ 411,340.1 /$ year & $\$ 3,526,789.7$ & $\$ 411,340.1 /$ year \\
\hline & Maintenance cost & Annually & $\$ 544.2 /$ year & $\$ 4665.5$ & $\$ 544.2 /$ year \\
\hline \multirow{6}{*}{ GEWPro } & \multicolumn{2}{|c|}{ Initial cost } & $\$ 60,567.7$ & $\$ 60,567.7$ & $\$ 7064.0 /$ year \\
\hline & \multicolumn{2}{|c|}{ Yearly Expenses } & $\$ 351,820.0 /$ year & $\$ 3,016,470.2$ & $\$ 351,820.0 /$ year \\
\hline & \multirow{4}{*}{ Maintenance cost } & Annually & $\$ 716.1 /$ year & $\$ 6139.5$ & $\$ 716.1 /$ year \\
\hline & & $\begin{array}{l}\text { Every } 4 \text { years } \\
\text { (at 4th year) }\end{array}$ & \multirow{2}{*}{$\$ 16,099.0 / 4$ year } & $\$ 14,359.4$ & $\$ 1674.8 /$ year \\
\hline & & $\begin{array}{c}\text { Every } 4 \text { years } \\
\text { (at 8th year) }\end{array}$ & & $\$ 12,807.8$ & $\$ 1493.8 /$ year \\
\hline & & Every 5 years & $\$ 6576.9 / 5$ year & $\$ 5701.0$ & $\$ 664.9 /$ year \\
\hline
\end{tabular}

\subsubsection{LCC Analysis of GEWPro}

\section{- $\quad$ Net Present Worth; NPW}

Net present worth analysis is a method for comparing the cash flow of a subject under economic analysis based on its present value. In this study, the present worth was calculated based on the cost difference incurred over ten years of operation (expected service life of GEWPro) using the conventional method versus automated method using GEWPro. According to the economic analysis using net present worth, the present worth of net profit was calculated to be $\$ 430,404$, as shown in Equation (4).

$$
\text { Net Present Worth (NPW) }
$$

$=$ Present worth of benefit - Present worth of $\cos t$

$=\left(\mathrm{EP}_{\mathrm{C}}-\mathrm{EP}_{\mathrm{G}}\right)-\left\{\left(\mathrm{IP}_{\mathrm{G}}-\mathrm{IP}_{\mathrm{C}}\right)+\left(\mathrm{MP}_{\mathrm{G}}-\mathrm{MP}_{\mathrm{C}}\right)\right\}$

$$
=(\$ 3,526,789.7-\$ 3,016,470.2)-\{(\$ 60,567.7-\$ 14,994.5)+
$$

$$
(\$ 6139.5+\$ 14,359.4+\$ 12,807.8+\$ 5701)-\$ 4665.5\}
$$

$$
=\$ 430,404
$$




\section{- $\quad$ Benefit/Cost ratio}

The $\mathrm{B} / \mathrm{C}$ ratio is used in economic analysis where the economic payability is determined by calculating the ratio of the present worth of the incurred benefit to the present worth of the incurred cost. The system is economically viable if the $\mathrm{B} / \mathrm{C}$ ratio is greater than one. In this study, as per Equation (5), the $B / C$ ratio was calculated to be 6.39 based on the ratio of the incurred benefit and incurred cost of using conventional and automated methods over ten years (expected service life of GEWPro).

$$
\begin{aligned}
& \quad \text { Benefit/Cost ratio }(\mathrm{B} / \mathrm{C}) \\
& =\text { Present worth of benefit / Present worth of cost } \\
& =\left(\mathrm{EP}_{\mathrm{C}}-\mathrm{EP}_{\mathrm{G}}\right) /\left\{\left(\mathrm{IP}_{\mathrm{G}}-\mathrm{IP}_{\mathrm{C}}\right)+\left(\mathrm{MP}_{\mathrm{G}}-\mathrm{MP}_{\mathrm{C}}\right)\right\} \\
& =(\$ 3,526,789.7-\$ 3,016,470.2) /\{(\$ 60,567.7-\$ 14,994.5) \\
& +(\$ 6139.5+\$ 14,359.4+\$ 12,807.8+\$ 5701)-\$ 4665.5\} \\
& =6.39
\end{aligned}
$$

- $\quad$ Break-even point

The break-even point is a point at which the present values of the incurred benefit and cost are the same [19]. The actual gain from using the GEWPro begins to occur after the break-even point. In this study, the break-even point was found to be 1.36 years (16.3 months) according to Equation (6).

$$
\text { Break - even point }
$$

$\rightarrow$ Finding the year(n)when present worth of benefit $=$ present worth of $\cos t$

$$
\rightarrow \frac{(1+i)^{n}-1}{i(1+i)^{n}}=\left\{\left(\mathrm{IP}_{\mathrm{G}}-\mathrm{IP}_{\mathrm{C}}\right)+\left(\mathrm{MP}_{\mathrm{G}}-\mathrm{MP}_{\mathrm{C}}\right)\right\} /\left(\mathrm{EA}_{\mathrm{C}}-\mathrm{EA}_{\mathrm{G}}\right)
$$

$\rightarrow$ when the interest rate $(i)$ is $2.90 \%$,

$$
\begin{aligned}
\frac{(1+0.029)^{n}-1}{0.029(1+0.029)^{n}} & \\
& =\{(\$ 60,567.7-\$ 14,994.5) \\
& +(\$ 6139.5+\$ 14,359.4+\$ 12,807.8+\$ 5701)-\$ 4665.5\} \\
& /((\$ 411,340.1 / \text { year }-\$ 351,820.0 / \text { year })) \\
& =1.34 \\
\therefore \mathrm{n}=1.36 \text { year } &
\end{aligned}
$$

- Cost saving effect using equivalent annual worth method

The analysis of the construction cost saving effect utilizes the equivalent annual worth method in obtaining the ratio of the present worth of cost saving using automated method over the conventional method. Applying Equation (7), the cost saving effect of using the GEWPro was $12.2 \%$ for this study.

Cost saving effect using equivalent annual worth method $=($ annual cost of conventional method - annual cost of automated method $)$

/ (annual cost of conventional method)

$=\left\{\left(\mathrm{IA}_{\mathrm{C}}+\mathrm{EA}_{\mathrm{C}}+\mathrm{MA}_{\mathrm{C}}\right)-\left(\mathrm{IA}_{\mathrm{G}}+\mathrm{EA}_{\mathrm{G}}+\mathrm{MA}_{\mathrm{G}}\right)\right\} /\left(\mathrm{IA}_{\mathrm{C}}+\mathrm{EA}_{\mathrm{C}}+\mathrm{MA}_{\mathrm{C}}\right)$

$=\{(\$ 1748.9 /$ year $+\$ 411,340.1 /$ year $+\$ 544.2 /$ year $)$

$-(\$ 7064.2 /$ year $+\$ 351,820.0 /$ year $+\$ 716.1 /$ year $+\$ 1674.8 /$ year

$+\$ 1493.8 /$ year $+\$ 664.9 /$ year $)\} /(\$ 1748.9 /$ year $+\$ 411,340.1 /$ year $+\$ 544.2 /$ year $)$

$=0.122$

\subsection{Sensitivity Analysis}

\subsubsection{Setting Major Variables for Sensitivity Analysis}

Among the assumptions and variables previously established, sensitivity analysis was performed on the variables expected to have a significant influence or variables that must be considered 
for the future commercialization of GEWPro. The three significant variables finally selected for performing sensitivity analysis were (1) work time of each work process in the automated method by GEWPro (preparation and installation work, painting work, disassembly and horizontal moving work); (2) projected expenses of GEWPro equipment (initial cost of GEWPro, maintenance cost of GEWPro); and (3) interest rate. The sensitivity ranges for each variable in performing sensitivity analysis were established, as shown in Table 8.

Table 8. Setting ranges of the significant variables for sensitivity analysis.

\begin{tabular}{ccc}
\hline \multirow{2}{*}{$\begin{array}{c}\text { (a) GEWPro Work Time of Each } \\
\text { Work Process }\end{array}$} & Preparation and installation work & $10 \sim 140[\mathrm{~min}]$ \\
\cline { 2 - 3 } & \multicolumn{1}{c}{ Painting work } & $5 \sim 12[\mathrm{~m} / \mathrm{min}]$ \\
\cline { 2 - 3 } & Disassembly work and horizontal movement & $1 \sim 13[\mathrm{~min} / \mathrm{each}]$ \\
\hline \multirow{2}{*}{$\begin{array}{c}\text { (b) GEWPro Equipment } \\
\text { Projected Expenses }\end{array}$} & GEWPro initial cost & $-50 \sim+50 \%[\$]$ \\
\hline & GEWPro maintenance cost & $0.5 \sim 6[\%]$ \\
\hline
\end{tabular}

\subsubsection{Sensitivity Analysis}

\section{- $\quad$ GEWPro work time of each work process}

Sensitivity analysis regarding the work time of each work process of GEWPro was performed because it has a direct impact on work productivity, which in turn has a decisive effect on the result of LCC analysis. According to sensitivity analysis of the GEWPro work time of each work process, even if the time required for preparation and installation work process varies within the sensitivity range set in Table 8 (a), the use of GEWPro was deemed to be economical (Figure 6a). On the other hand, it was observed to be uneconomical if the speed of painting work drops below $5 \mathrm{~m} / \mathrm{min}$ (Figure $6 \mathrm{~b}$ ) or if the time for each disassembly and horizontal moving work process exceeds $13 \mathrm{~min}$ (Figure 6c). Therefore, to secure the economic viability of GEWPro, it is recommended that the painting work process be maintained at least $5 \mathrm{~m} / \mathrm{min}$ (currently, $6.2 \mathrm{~m} / \mathrm{min}$ ) while keeping the disassembly and horizontal moving work to be done within $13 \mathrm{~min} /$ process (currently, $8.4 \mathrm{~min} /$ process).

\section{- $\quad$ GEWPro equipment projected expensess}

Sensitivity analysis of the GEWPro equipment cost is essential to enhance the reliability of economic analysis because the projected expenses of GEWPro (i.e., initial cost, and maintenance cost) can vary according to the manufacturing process and the supply/demand of GEWPro (particularly the maintenance cost, because it can be generated randomly during the expected service life of GEWPro). The results of sensitivity analysis on the projected expenses of GEWPro equipment (Figure $6 \mathrm{~d}, \mathrm{e}$ ) suggests that even if the GEWPro equipment projected expenses vary within the sensitivity range set in Table 8 (b), the use of GEWPro is economical.

\section{- Interest rate to reflect economic condition}

In this study, LCC analysis was conducted using the interest rate derived from the average inflation rate over the last 10 years in South Korea. Because interest rates can fluctuate depending on the economic conditions at home and abroad, it is imperative that sensitivity analysis is performed to enhance the analysis reliability. As shown in Figure 6f, sensitivity analysis showed that even if the interest rate varies within the sensitivity range set in Table 8 (c), the use of GEWPro is economical. 


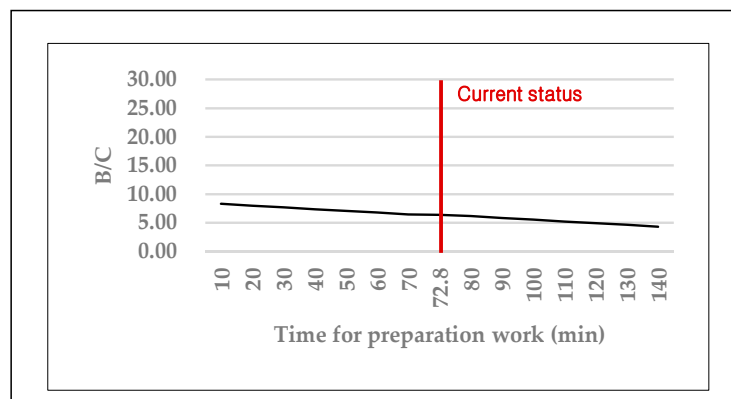

(a) Changes in $\mathrm{B} / \mathrm{C}$ in accordance with the time for preparation work process

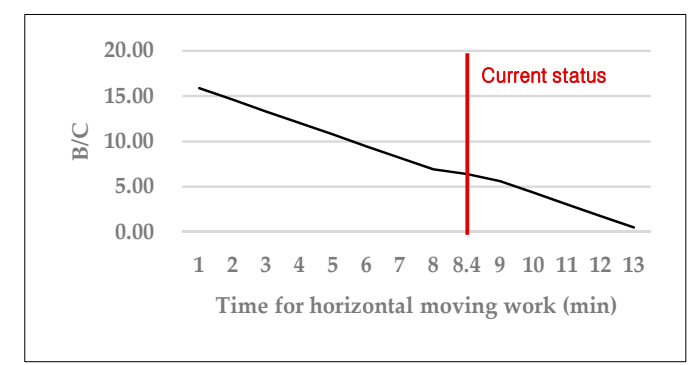

(c) Changes in $\mathrm{B} / \mathrm{C}$ in accordance with the time for horizontal moving work process

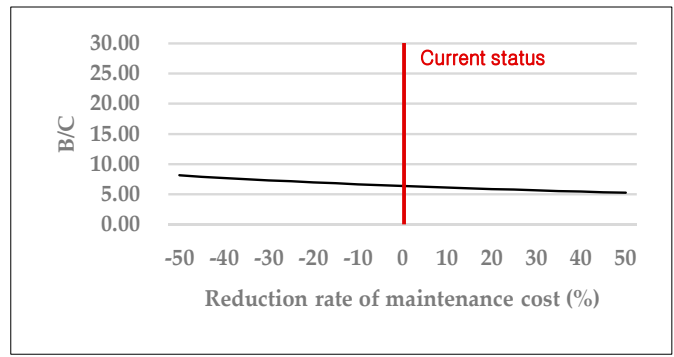

(e) Changes in $\mathrm{B} / \mathrm{C}$ in accordance with maintenance cost

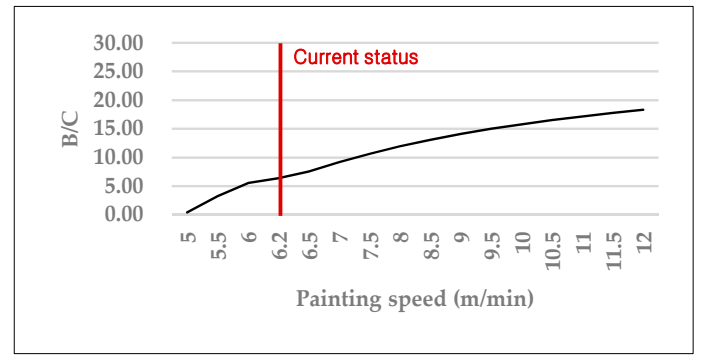

(b) Changes in $\mathrm{B} / \mathrm{C}$ in accordance with the speed of painting work

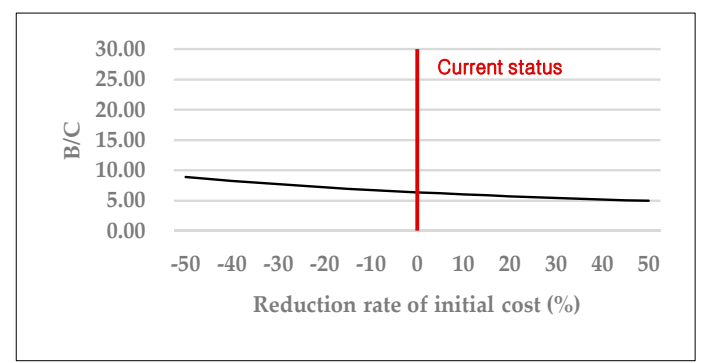

(d) Changes in B/C in accordance with initial cost

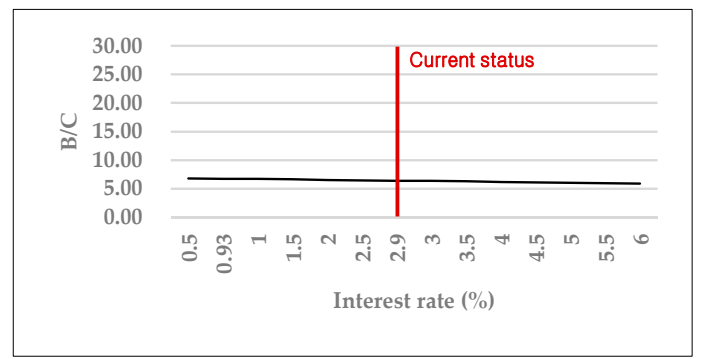

(f) Changes in $\mathrm{B} / \mathrm{C}$ in accordance with interest rate

Figure 6. Results of sensitivity analysis.

\section{Conclusions}

This study developed a performance evaluation and LCC analysis model and used the model to evaluate the performance and analyze the LCC of a GEWPro, which was developed to improve the problems related to conventional exterior wall painting work. The results of the study are as follows:

(1) According to the survey conducted to analyze the characteristics and problems related to exterior wall painting work, issues with the work productivity and product quality arose due to the aging of skilled exterior wall painters and the difficulty in the supply of a new workforce. In particular, $66 \%$ of the survey respondents perceived the risk of exterior painting work to be high and recognized that preparing alternatives, such as automation (utilizing robots, etc.) of exterior painting work was urgent.

(2) To meet these needs and automate the exterior painting work, a Gondola-type Exterior Wall Painting robot (GEWPro) was recently developed in South Korea. This study developed a performance evaluation and LCC analysis model for GEWPro based on an understanding of the conventional exterior work characteristics and an analysis of the specifications and performance of GEWPro.

(3) According to the performance evaluation of GEWPro, productivity of the automated method using GEWPro was $16.8 \%$ superior to the conventional method. Moreover, LCC analysis of 
GEWPro showed that the present net profit, $\mathrm{B} / \mathrm{C}$ ratio, break-even point, and annual construction cost saving rate was $\$ 430,404,6.39,1.36$ years, and $12.2 \%$, which showed that the use of GEWPro was economically more efficient and viable compared to the conventional method.

(4) According to sensitivity analysis, which was performed to improve the reliability of a performance evaluation and LCC analysis of GEWPro, among the six major variables identified for sensitivity analysis, four variables (preparation and installation work process, GEWPro initial cost, maintenance cost, and interest rate) had a very low impact on the economic efficiency of GEWPro within the set sensitivity range. To secure the economic efficiency of using GEWPro over the conventional method, however, the speed of the painting work process should be greater than $5 \mathrm{~m} / \mathrm{min}$ (currently, $6.2 \mathrm{~m} / \mathrm{min}$ ), whereas the disassembly and horizontal moving work should be done within $13 \mathrm{~min} /$ process (currently, $8.4 \mathrm{~min} /$ process).

Regarding economic analysis, although this study only considered the quantitative resources and expenses, such as equipment and labor cost, it is expected that the economic reliability and validity of the automated method would be furthered if additional consideration is given to qualitative factors, such as safety enhancement and uniformity in the quality of work brought by the automated method. Finally, authors need to consistently experiment and verify the sustainable applicability and operational stability of GEWPro on construction sites. For this, a number of field trials and case studies should be carried out in the near future.

Acknowledgments: This work was supported by INHA UNIVERSITY Research Grant.

Author Contributions: Dong-Jun Yeom conceived the idea for this study and wrote the manuscript. Eun-Ji Na and Mi-Young Lee designed the early methodology. Yoo-Jun Kim contributed to some of the LCC analysis and editing the paper. Young-Suk Kim and Chung-Suk Cho conceived the idea, supervised the research, and revised the manuscript. All authors read and approved the final manuscript.

Conflicts of Interest: The authors declare no conflict of interest.

\section{Nomenclature}

\begin{tabular}{|c|c|}
\hline $\mathrm{AB}$ & Annual Benefit by the automated method (\$/year) \\
\hline $\mathrm{B} / \mathrm{C}$ & Benefit/Cost \\
\hline $\mathrm{EA}_{\mathrm{C}}$ & Yearly Expenses of the conventional method at Annual worth (\$/year) \\
\hline $\mathrm{EA}_{\mathrm{G}}$ & Yearly Expenses of the automated method at Annual worth (\$/year) \\
\hline $\mathrm{EC}_{\mathrm{C}}$ & Yearly Expenses of the conventional method at Cash-flow (\$) \\
\hline $\mathrm{EC}_{\mathrm{G}}$ & Yearly Expenses of the automated method at Cash-flow (\$) \\
\hline $\mathrm{Em}^{2} \mathrm{C}$ & Expenses of the conventional method per $\mathrm{m}^{2}\left(\$ / \mathrm{m}^{2}\right)$ \\
\hline $\mathrm{Em}^{2} \mathrm{G}$ & Expenses of the automated method per $\mathrm{m}^{2}\left(\$ / \mathrm{m}^{2}\right)$ \\
\hline $\mathrm{EP}_{\mathrm{C}}$ & Yearly Expenses of the conventional method at Present worth (\$) \\
\hline $\mathrm{EP}_{\mathrm{G}}$ & Yearly Expenses of the automated method at Present worth (\$) \\
\hline GEWPro & Gondola-type Exterior Wall Painting robot \\
\hline $\mathrm{IA}_{\mathrm{C}}$ & Initial cost of the conventional method at Annual worth (\$/year) \\
\hline $\mathrm{IA}_{\mathrm{G}}$ & Initial cost of the automated method at Annual worth (\$/year) \\
\hline $\mathrm{IC}_{\mathrm{C}}$ & Initial cost of the conventional method at Cash-flow $(\$)$ \\
\hline $\mathrm{IC}_{\mathrm{G}}$ & Initial cost of the automated method at Cash-flow (\$) \\
\hline $\mathrm{IP}_{\mathrm{C}}$ & Initial cost of the conventional method at Present worth (\$) \\
\hline $\mathrm{IP}_{\mathrm{G}}$ & Initial cost of the automated method at Present worth $(\$)$ \\
\hline LCC & Life Cycle Cost $(\$)$ \\
\hline $\mathrm{LPP}_{\mathrm{C}}$ & Labor Productivity of a Painter in the conventional method $\left(\mathrm{m}^{2} / \mathrm{man}\right)$ \\
\hline $\mathrm{MA}_{\mathrm{C}}$ & Maintenance cost of the conventional method at Annual worth (\$/year) \\
\hline $\mathrm{MA}_{\mathrm{G}}$ & Maintenance cost of the automated method at Annual worth (\$/year) \\
\hline $\mathrm{MC}_{\mathrm{C}}$ & Maintenance cost of the conventional method at Cash-flow (\$) \\
\hline $\mathrm{MC}_{\mathrm{G}}$ & Maintenance cost of the automated method at Cash-flow (\$) \\
\hline $\mathrm{MP}_{\mathrm{C}}$ & Maintenance cost of the conventional method at Present worth (\$) \\
\hline $\mathrm{MP}_{\mathrm{G}}$ & Maintenance cost of the automated method at Present worth (\$) \\
\hline
\end{tabular}




$\begin{array}{ll}\text { PER } & \text { Performance Evaluation Result } \\ \mathrm{R}_{\mathrm{C}} & \text { Resources required for the conventional painting work per day } \\ \mathrm{r}_{\mathrm{CC}} & \text { Consumable resources required for the conventional painting work per day } \\ \mathrm{r}_{\mathrm{CG}} & \text { Consumable resources required for the automated painting work per day } \\ \mathrm{r}_{\mathrm{EC}} & \text { Equipment resources required for the conventional painting work per day } \\ \mathrm{r}_{\mathrm{EG}} & \text { Equipment resources required for the automated painting work per day } \\ \mathrm{R}_{\mathrm{G}} & \text { Resources required for the automated work per day } \\ \mathrm{r}_{\mathrm{LC}} & \text { Laborer resources required for the conventional painting work per day } \\ \mathrm{r}_{\mathrm{LG}} & \text { Laborer resources required for the automated painting work per day } \\ \mathrm{r}_{\mathrm{MC}} & \text { Material resources required for the conventional painting work per day } \\ \mathrm{r}_{\mathrm{MG}} & \text { Material resources required for the automated painting work per day } \\ \mathrm{T}_{\mathrm{C}} & \text { Total work time of the conventional method }(\mathrm{h}) \\ \mathrm{T}_{\mathrm{G}} & \text { Total work time of the automated method }(\mathrm{h}) \\ \mathrm{TPA} & \text { Total Painting Area of the Building }\left(\mathrm{m}^{2}\right) \\ \mathrm{TPAy} & \text { Total Painting Area per year }(\$ / \text { year) } \\ \mathrm{WDy} & \text { The number of Workable Days per year }(\text { day } / \text { year) } \\ \mathrm{WPh}_{\mathrm{C}} & \text { Work Productivity of the conventional method per hour }\left(\mathrm{m}^{2} / \mathrm{h}\right) \\ \mathrm{WPh} & \text { Work Productivity of the automated method per hour }\left(\mathrm{m}^{2} / \mathrm{h}\right)\end{array}$

\section{References}

1. Statistics Korea. Annual Construction Report of Apartment Complex. Available online: http://www.kostat. go.kr (accessed on 15 May 2017).

2. Ministry of Land. Infrastructure and Transport in Korea, Enforcement Regulations of Multi-family Housing Management. Available online: http:/ / www.law.go.kr (accessed on 15 May 2017).

3. Korea Agency for Infrastructure Technology Advancement. Final Report of Maintenance Robot. Available online: https: / /www.kaia.re.kr/portal/landmark/readTskFinalView.do?tskId=55292\&yearCnt= $5 \&$ menuNo=200100 (accessed on 15 October 2015).

4. Slocum, A.; Schena, B. Blockbot: A Robot to Automate Construction of Cement Block Walls. Robot. Autonom. Syst. 1988, 4, 111-129. [CrossRef]

5. Pritschow, G.; Dalacker, M.; Kurz, J.; Gaenssle, M. Technological Aspects in the Development of a Mobile Bricklaying Robot. Autom. Constr. 1996, 5, 3-13. [CrossRef]

6. Lichtenberg, J. The Development of a Robot for Paving Floors with Ceramic Tiles. In Proceedings of the 20th International Association for Automation and Robotics in Construction, Eindhoven, Holland, 2003; pp. 85-88. Available online: http:/ / www.irbnet.de/daten/iconda/CIB13500.pdf (accessed date 11 October 2017).

7. Lee, J.; Yoo, H.; Kim, Y.; Lee, J.; Cho, M. The Development of a Machine Vision-Assisted Tele-operated Pavement Crack Sealer. Autom. Constr. 2006, 15, 616-626. [CrossRef]

8. Kim, Y.; Lee, J.; Kim, S.; Lee, J. Development of an Automated Machine for PHC Pile Head Grinding and Crushing Work. Autom. Constr. 2009, 18, 737-750. [CrossRef]

9. Kim, Y.; Lee, J.; Yoo, H.; Lee, J.; Jung, U. A Performance Evaluation of a Stewart Platform based Hume Concrete Pipe Manipulator. Autom. Constr. 2009, 18, 665-676.

10. Sherif, Y.; Kolarik, W. Life Cycle Costing: Concept and Practice. Omega 1981, 9, 287-296. [CrossRef]

11. Schau, E.M.; Traverso, M.; Lehmann, A.; Finkbeiner, M. Life Cycle Costing in Sustainability Assessment-A Case Study of Remanufactured Alternators. Sustainability 2011, 3, 2268-2288. [CrossRef]

12. Özkan, A.; Günkaya, Z.; Tok, G.; Karacasulu, L.; Metesoy, M.; Banar, M.; Kara, A. Life Cycle Assessment and Life Cycle Cost Analysis of Magnesia Spinel Brick Production. Sustainability 2016, 8, 662. [CrossRef]

13. Cho, J.; Yoo, H.; Choi, S.; Kim, Y. Wind Resistance Performance Analysis of Automated Exterior Wall Painting Robot for Apartment Buildings. KSCE J. Civ. Eng. 2015, 19, 510-519. [CrossRef]

14. Kim, Y. Development of Remote Control Device for Automation of Road Surface Maintenance; Research Report; Ministry of Land, Infrastructure and Transport (MOLIT): Sejong, Korea, 2004.

15. Kim, Y.; Lee, J. A Conceptual Model and Technical—Economical Feasibility Analysis of Apartment Exterior Wall Painting Robot. KICEM Korea Inst. Constr. Eng. Manag. 2006, 22, 139-150. 
16. Korea Occupational Safety \& Health Agency. Suspended Scaffold Safety Guidelines. Available online: http: / / www.kosha.or.kr (accessed on 7 June 2017).

17. Korea Land \& Housing (LH) Corporation. Painting Specifications. Available online: http://www.lh.or.kr (accessed on 10 June 2017).

18. Korea Meteorological Administration. Available online: http://www.kma.go.kr (accessed on 11 June 2017).

19. Remer, D.; Tu, J.; Carson, D.; Ganiy, S. The State of the Art of Present Worth Analyses of Cash Flow Distributions. Eng. Costs Prod. Econ. 1984, 7, 257-278. [CrossRef]

(C) 2017 by the authors. Licensee MDPI, Basel, Switzerland. This article is an open access article distributed under the terms and conditions of the Creative Commons Attribution (CC BY) license (http:/ / creativecommons.org/licenses/by/4.0/). 